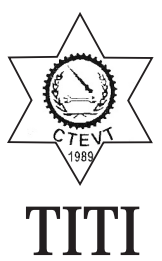

DOI: https://doi.org/10.3126/jtd.v5i0.33893

ISSN: 2392-4578(Online)

\title{
Empowering Tharu and Bote Women Through Vocational Skills: A Case of Amaltari Homestay
}

\author{
Surya Prasad Newpane \\ Freelancer Consultant \\ Governance and Capacity Building \\ Corresponding Email: suryanewpane@kusoed.edu.np
}

\begin{abstract}
Tharu and Bote are indigenous groups of Nepal. They have been surviving by using their traditional skills and indigenous knowledge. However, at present, they have gradually started shifting their survival skills for their economic and socio-cultural development. Homestay is one such initiation and women's role in particular has been vital to this initiation which is usually unnoticed in the society. In connection to this, this paper incorporates the stories of women who uses their vocational skills to run a homestay in their community. For this, a qualitative approach was used and Amaltari homestay which is run by the Tharu and Bote of Nawalparasi was selected as the research site. Several rounds of interactions with owners of the homestay, group discussion with community people and observation were used to collect information. The study found that the women of Tharu and Bote community in Amaltari homestay village have been using their skills in the area of hospitality, cooking traditional foods and crafting bamboo and wooden goods that can be sold to the guests as souvenir. Furthermore, they have been able to keep financial records of their business as well. In this sense, the homestay has significantly contributed to the indigenous practice and has been supportive in uplifting the Tharu and Bote women socially and culturally by using the traditionally learned vocational skills.
\end{abstract}

Keywords: Empowerment, homestay, indigenous, economic, sociocultural

\section{Introduction}

Tharu and Bote, indigenous groups of Nepal have been surviving by utilizing their traditional skills and indigenous knowledge (Bhattachan, 2012). More specifically, traditionally women of this indigenous community were living in a poor condition where they did not have access to education and other opportunities. However, recently the women in the community are performing additional role and still including their traditional ones. They run homestay in their community which has been an important means for transforming their economic and social condition. In a homestay, guest pay for their warm hospitality. Women's role along with their traditional skills has been particularly vital in the promotion of homestay which is generally unnoticed in the society. In this context, this paper interprets the contribution of homestay in empowering the Tharu and Bote women in the Amaltari homestay village. 
According to the people in the community, in the beginning, the women of these communities were provided with an opportunity to enhance different traditional skills and to gain new vocational skills and knowledge. The opportunity helped to enhanced their vocational skills which they were using for generations such as hospitality, cooking traditional foods, crafting bamboo and wooden goods to be sold as a souvenir and keeping financial records of their business as well. This also became a milestone in preserving their traditional and cultural practices.

With this background, I have carried out this research for identifying the role of homestay in the empowerment women from the Tharu and Bote community. The main purpose of this study was to explore the role of homestay enterprise in empowering the women through vocational skills which were promoted formally and informally after the establishment of homestay in my research site. Women who are directly involved in providing the homestay service have participated in this study.

\section{Indigenous Nationality and Tharu and Bote People}

The people who have a collective identity, own language, culture, tradition, and social structure are the indigenous people and also known as Adivasi Janajati in Nepal (Limbu, 2015). So, Adivasi Janajati are indigenous people who have their own unique culture, language, and belief system (Jha, 2019). Taru and Bote are also indigenous people who have their own culture and language. these communities have their own written and unwritten histories, traditional homeland and geographical areas, plus egalitarian social structures (Bhattacha, 2012). In this sense, indigenous people who have various identities in Nepal have their unique socio-cultural background.

Tharu people live in different areas of Tarai (plane) whereas Bote people live in inner Tarai and Tanahu district of Nepal. Sunsari, Dang, Bardiya, Kailali districts of Nepal are densely populated areas of Tharu people (Government of Nepal ([GON], 2012).
Similarly, Tharu people also lives in Bara, Parsa, Chitwan, Rupandehi, Kapilbastu, Banke, Saptari, Kanchanpur and they are also found residing in Morang, Nawalpur and Nawalparasi districts. In the same way, the main residential areas of the Bote people are Chitawan, Tanahun and Nawalpur districts (GON, 2012). Bote people mostly live along the riverside of Narayani River and Inner Terai area. According to the National Indigenous Women's Federation (NIWF, 2018), the Bote people are categorized as highly marginalized indigenous people whereas Tharus are marginalized.

\section{Women of Tharu and Bote Community}

United Nations Declaration on the Rights of Indigenous People (United Nations [UN], 2007), article 21 (1), 22 (1) and (2) highly emphasize that protection of rights of indigenous people including indigenous women, elderly people, children and disabled people. It also urges the nation for ensuring socio-economic empowerment, access to vocational training and other basic requirements for a dignified life. In Nepal's context, indigenous women are facing different types of discriminations and they are living in an economically, socially, politically and culturally vulnerable situation (National Indigenous Women Federation [NIWF], 2018). Physical and psychological domestic violence against indigenous women is increasing in their society which is a challenge for women empowerment (Luithue \& Tugendhar, 2013). Indigenous women around the world face violence within their communities which is in higher rates than that experienced by nonindigenous women (Nagy, 2015). In this sense, women from Tharu and Bote community of Nepal are not far away from this situation, which is the obstacle in the overall development of society.

\section{Vocational Skill for Developing Human Capital}

Human capital is an important source of economic and socio-cultural development of any society (Matovac et al., 2010). Development of human capital is important for the achievement of sustainable economic growth and development of a society. In 
the lack of appropriate plan and investment in the development of human capital in the country, sustainable economic growth and development would only be a mere wish, never a reality (Eigbiremolen \& Anaduaka, 2014). Therefore, it is a key prerequisite for a country's socio-economic, socio-cultural and political transformation.

To accelerate the human capability, three models of Technical Vocational Education and Training (TVET) are in practice in Nepal which is formal, nonformal and informal. Technical Vocational Education and Training (TVET) enhances the skill of people in specific areas which supports better performance in a profession or to start and run a new occupation (Asian Development Bank [ADB], 2015). That is why it can support to generate employment with perfect skill. Similarly, Technical Vocational Education and Training (TVET) is organized and unstructured which can take place anywhere, any time, learning by doing or informal learning process (Bagale, 2015). Enhancing vocational skill is essential for all and plays a vital role for empowering poor, marginalized and women in the context of Nepal.

\section{Policies Regarding Empowerment}

Sustainable Development Goal (SDGs), goal number 8 has indicated about the promotion of inclusive and sustainable economic growth of people particularly the marginalized and poor (United Nations ([UN], 2015). It also focuses on the opportunities of job and appropriate working environment for all the working-age population. Although some other goals are also interconnected with SDGs goal number eight. Goal one focuses on ending poverty in all its forms. In the context of Nepal, the government aims to bring down the percentage of people living below the poverty line to 4.9 per cent and to reduce multi-dimensional poverty to 10 percent by 2030 (National Planning Commission [NPC], 2015). Likewise, goal two focuses on ending hunger and achieving food security, improving nutrition as well. And, goal three highlights the assurance of healthy lives, and the promotion of well-being for all at all time. In the same way, goal four is for ensuring quality education for all (NPC, 2017). Having mentioned four goals, another goal which is the eighth one that reflects the economic empowerment, social empowerment through the improvement of nutrition, health and education for all people. To highlight, goal five is more important in terms of women empowerment. This goal is for achieving gender equality and empowering all women and girls (NPC, 2015). Nepal is in line to achieve gender equality and women's empowerment, however, achievements vary where poor women are in the position of less equality. But still, the discrimination and violence against women and girls are prevalent in the country. Women's participation in public sector decision making is low (NPC, 2017). In this sense, there are many opportunities to be created with interventions for empowering women.

Constitution of Nepal has the provisions that all Nepali citizens are free to do business, employment, and establish industries in the country (Nepal Law Commission, [NLC], 2015). Thirty-one fundamental rights of Nepali citizens are consistently secured from article 16 to article 46 in the constitution of Nepal but rights to live with dignity (article 16), rights to equality (article 18), rights against exploitation (article 29), rights of education (article 31 ), rights of employment (article 33), rights of women (article 38) and rights of social justice ( article no 42) highlights towards the empowerment of women, poor and backwards people (NLC, 2015). For ensuring these fundamental rights of people through policy advocacy and capacity building of women and Adivasi Janajati, constitutional commissions are also envisioned in the constitution of Nepal. Among those commissions, National Commission of Women is for ensuring the rights of women; National Commission of Adivasi Janajati (Indigenous Nationalities) is formulated for ensuring the rights of all Indigenous Nationalities; Commission of Tharu is functioning for rights of Tharu people, and Commission of Inclusion is for ensuring the social inclusion and social justice of those people who are excluded in different sectors. 


\section{Women Empowerment}

According to the empowerment theory of Perkins and Zimmerman (1995), participation for achieving own goal, the ability of access to resources, and normally and critically understand the socio-political scenario is empowerment. Steps to achieve set goals, access and control to resource and thinking critically about the social and political context are the symbols of empowered personality. The process such as actions of a person, activities of the society and social structures to empower the people is empowerment (Zimmerman, 2000). Thus, empowerment is contextual. It is people and society specific.

Empowerment is the ability to control over the life or health of a person, independency, ability to perform life responsibility, self-efficiency and self-steam (Tengland, 2007). Empowered personalities have control over their life and are able to perform their responsibility with freedom and self-steam. Major elements of empowerment are economic, human and social, political and cultural empowerment (Luttrell et al., 2009). All these elements are interdependent and interrelated. That is why the only economically empowered person, who is not empowered socially, politically and culturally, can not have access and control over the political and social resources.

Women empowerment is determined by their involvement in the decision-making process and enhancing their self-confidence level, by their status and by their level of social and political participation, by their power to control over their income, their degree of knowledge on social issue and awareness, awareness on problems about family relation and violence against them (Sharma, 2007). Women empowerment is the enhancing and having power for herself, her family and her society for the betterment of life. Women empowerment is not only limited to the economical self-reliance of women, but also includes the experience of gender equality, recognizes their identities and strength in all aspects of life (AI-Momani, 20019). In the sense, women empowerment is not only the use of power for access over the economic resources.

Women empowerment is being a complex sociological and economic issue which needs to measure on access to a resource, capability of decision making and capacity to take a stand (Roy et al., 2018). Major basic indicators of women empowerment are the mobility of women, legal awareness, participation in different organizations and decision-making process, access and control on own property, access to the opportunity to develop knowledge and skill, access to basic resources and services, involvement in the earning process through self and institutional employment and ability to raise voice against violence and injustice behaviour.

With the establishment of homestay business in Amaltari, women of the community got an opportunity to enhance their vocational skills nonformally and informally with the support of Homestay Management Community, Community Forest Group (CFG) and Chitwan National Park (CNP). As a result, the gained vocational skills became a tool for empowering them.

\section{Applied Research Approaches}

The qualitative approach was applied for carrying out this research. For this purpose, I selected homestay area of Amaltari village of Nawalpur district, Nepal as my research site. Three tools were used in the research site for collecting information for this research. First, I carried out unstructured interviews with three women, all of whom werer homestay owner. For this process, one woman from the Bote community and two from the Tharu ethnic group were interviewed. Second, I conducted Focus Group Discussion (FGD) as a tool of information collection. A total of 29 business women who are currently operating homestay service participated in this process in four groups. Probing questions, followup questions and exit questions were used in the FGD process. The discussion was mainly focused on the situation of the community before and after they started the homestay program and its contribution in women empowerment in this area. Impact of homestay in 
economic, social, cultural and political empowerment of women was the theme of the focus group discussion. Equally, another observation was made using a different tool for data collection. I observed the daily activities of women owner of the homestay. I observed their behaviour and activities such as guest receiving and welcoming, household management, role in decision making and participation in different meetings. I also observed their participation in Homestay Management Committee (HMC) meeting, Saving and Credit Group's (SCGs) meeting, Cooperative Management Committee (CMC) meeting, Community Forest Group (CFG) meeting and meeting of the School Management Committee (SMC).

Credibility is the major quality criteria for all types of qualitative research (Korstjens, \& Moser, 2018). To ensure credibility, I stayed in the research site and discussed with participants to collect information. Similarly, authenticity is another pillar to ensure quality in such research. Authenticity includes fairness or impartiality in the research process (Morrow, 2005). In this research, I gave equal priority to all my participants. I included their views without making it a different sense. In the process of writing, I did not pressure the participants for the information during the discussion. In the focus group discussion process, I tried to make the discussion more interactive. This helped all participants to actively participate in the process. I also used appropriate literature and reference materials for making discussion livelier.

\section{The Community Before Homestay Business}

Bagkot village of Amaltari area of Nawalpur district has been the habitat of Tharu and Bote people from many generations. According to few of the participants of the study, namely Shreejana, Kalpana and Meena(Suedonymes), Bote people had migrated to the Bagkot village of Amaltari area from Tanahu. Their main occupation was fishing and boating in the Narayani river. Tharu people migrated there from Chitwan district and their main occupation was agricultural farming. Nawalpur, Chitwan and Tanahu are neighbouring districts. Bagkot village of Amaltari is situated nearby Narayani river and this place is fertile for farming and fishing as well. According to my participants, they migrated there for fishing and agriculture but no written pieces of evidence were found regarding when and how they migrated there and no one was able to remember about it. According to my participants, women and children of this community were more vulnerable than men. Furthermore, women and girls were prone to different types of domestic violence.

Meena added, "When I came to my husband's house after marriage, my mother-in-law was pregnant with the ninth baby. Among eight, five were alive and three had died after birth. Two boys including my husband used to go to school to study. My motherin-law never went to the health post for health checkup including antenatal checkup. According to her, she gave all birth at home without any health care". The voice of Meena reflects the poor level of awareness about reproductive health and maternal care in the community. The only option was to pray to God for the life of the pregnant mother, antenatal baby, maternal mother and children.

Kalpana shared that both Bote and Tharu of Amltari community had their own rich culture. They had their own unique food, culture, dress, dance, song and language. They had their rituals and festive cultures, which they are declining because of the youths being connected with the so-called modern culture and their indifference towards the traditional culture. There was lack of basic needs and infrastructure, economic opportunity and social development. The livelihood of the people of that village was depended on women's earning from daily wages. Women in the community used to work as unskilled labour but men mostly stayed at home, drank alcohol and played cards. Other participants of the focus group discussion also supported the views of Kalpana.

Bagkot, Amaltari area is a buffer zone of Chitwan National Park. Amaltari Community Forest Group 
was instituted in the initiation of Chitwan National park. When the community forest group was formulated, it took initiation in improving the livelihood of community people through different supports and interventions. Because Amaltari is in the buffer zone of Chitwan National Park, this area $\mathrm{had} /$ has more potential for tourism promotion. The Amaltari Forest Group took initiation to develop community forest area as a tourism sport. In the same context, homestay service also started from 2012 in Amaltari village consisting of Tharu and Bote community in the initiation of Amaltari Community Forest Group. Now, they are functioning a total number of 32 homestay houses. Among them, six are run by Bote family whereas 26 are run by Tharu family. Women of Tharu and Bote communities are performing a major role in operating the homestay services.

During the focus group discussion, participants revealed that no one has any idea about when the Botes and Tharus started to live in these area but as my research participants remembers that in the past womensuffered from different types of misbehaviour from their husbands and senior male members. My participants had observed and experienced different forms of domestic violence against women in that community. Early marriage, polygamy, physical, and mental torture were some common issues among them.

Kalpana shared, "Now I am 52 years old. When I got married, I was still running on 13. There was a practice of child marriage which was mainly taken as labour force management at home. There was no priority for girl's education. Priority was not given even to boy's education". She added, "I never went school for study. My husband also did not go to school to study. I learned to read and write from informal education after establishing the homestay".

According to my participants at the focus group discussion, the economic condition of Bote and Tharu people of that community was very poor. They didn't have enough land of their own for agricultural farming. Moreover, there was also no such opportunity for a job. However, the women from the community used to go for seasonal work in other landlord's land in the nearby villages. The women from the community had the major responsibility of earning money for bread and clothes for the family whereas the men only ordered the women to go to work and earn. Men rarely went to work. Yet, the wages of female doing the same work was lower than that of the male workers. To sustain their living, they used to make local homemade wine to sellduring the seasonal work in the landlord's field but again, much of the homemade wine used to be consumed by the male members of their community. To mak matter worse, they used to fight or quarrel with other members of their community as well as within their family members after drinking alcohol. That was the reason why homemade alcohol became the major cause of domestic violence and it created trouble in the family.

My participants exposed that in-house activities were permanently allocated for women. Cleaning, cooking, caring of children, rearing of cattle and chicken, serving guests, and providing service to senior members of family were fixed responsibilities of women. If they had time after completing these all responsibilities, they used to go to the river site for fishing. Only a few male members from the community used to go to India in search of employment for six to nine months. Almost every male member used to be engaged in drinking alcohol and playing cards. Kalpana added, "The level of awareness about health and sanitation of our village was poor. Equally, health and sanitation facility also was out of our access. Almost every member was dependent on a local healer rather than taking service from a health person." She again added, "In my family, I lost my an elder sister and a smaller brother to an unknown disease at different point of time. There was no trend to go to the health post or hospital for treatment. My parents took my sister to the local healer for treatment. She was suffering from severe fever. Unfortunately, she died from the fever. Similarly, my brother suffered from stomach 
pain. The local healer performend his treatment but he could not treat her brotherl. Kalpana again shared that the situation of health and sanitation of Amaltari, Bagkot village is not as previous. People of this community are health-conscious and the sanitation of the community is also well maintained by the community in the initiation of women.

Participants of FGD shared that the birth rate was also high and the child mortality was even higher because of poor health, lack of access to health service, and poor sanitation. There was a lack of consciousness about health, sanitation, and education.

According to participants, the situation of infrastructure development of the community was also poor. There was a primary school but it was barely functional due to the absence of adequate teachers and students. There was no road facility. There was no water supply and sanitation facilities. There was no irrigation facility for their field. There was no telephone and electricity facility in the Amaltari, Bagkot community making the daily lives and livelihood of the people living there very difficult.

\section{An Eye-Opener for Changing Community}

According to the participants of FGD, Chitwan National Park started working with the Community Forest Group for the conservation of biodiversity of that area. It designed and implemented many different community development activities to support and to enable the capacity of Amaltari Community Forest Group. Conservation of wildlife and all the biodiversity through mobilization of the local community was the main aim. However, without improving the livelihood of the local people, conservation was not possible. Chitwan National park applied a strategy to mobilize the local organizations to achieve the target. It initiated to build the capacity of Amaltair Community Forest Group and mobilize them for community transformation. As a result, Amaltari Community Forest Group became active in the conservation process and livelihood improvement of its members.
Participant of Key Informants' Interview (KII) Shreejana shared that women of that community were in a vulnerable situation because of gender discrimination, male-dominated social culture and gender-based violence. In addition to this, women's productive social role was depended on the jungle in the buffer zone area where they collected grass, firewood and different wild vegetables. Shreejana added that the people of that community also went fishing in the riverside and ponds in the forest area. Amaltari Community Forest Group organized different awareness related training for gender equality and eliminated all types of violence against women in that community. As a result, women started to take active role in the Community Forest Group. At the same time, homestay was established to promote their livelihood through rural tourism.

The participants of the focus group discussion shared that men and women members of Amaltari Community Forest Group came in the frontline for biodiversity conservation but improving the livelihood was still challenging for them. Empowering the women was another challenge because they had no economic power. Women participation in the social, political and economic role was important for successfully mobilizing the community in biodiversity conversation. Because of the initiation of Amaltari Community Forest Group, conservation became a success and possibility of that area for tourism promotion was realized as it was suitable for people who wants to enjoy the biodiversity, visit and observe beautiful forest, rhinos, deers and many types of beautiful birds.

Participants again shared that Amaltari Community Forest Group took the initiation to establish community homestay in 2012 which would help to promote rural tourism in this area and improve the livelihood of community people. At the initial phase, only 10 homestays were established. All types of responsibilities including the management were performed by men. When women of this area participated in the hospitality skill training, vocational training became an important milestone for 
empowering women. Because of the hospitality they provided, the flow of tourists increased and their earning rose accordingly. Gradually, they started to take part in the decision-making level of homestay management. Similarly, men of this community started being positive toward the women's community roles. Women started to fight jointly against all types of violence against them. Not only did the women stepped up in homestay's hospitality, but they also took this opportunity to participate in different vocational and skill-based training such as handicraft of bamboo, pig farming, poultry farming, cooking, tourist guide and hospitality of guest. These skills turned out to be the backbone for improving their livelihood. In the beginning, Amaltari Community Forest Group initiated to provide such types of skillbased training to the people of this community. Gradually, Homestay Management Committee started to take initiation for providing training opportunity to its members. Likewise, women from newly established Amaltari homestay houses got a chance to visit Dalla Gaun Homestay inBardiya. This three days exposer visit provided them with motivation, energy, skills and ideas.

Homestay of that village was well managed in my observation. The main responsibility of hospitality was undertaken by women and the men supported the role of the women. Different pictures showing the culture of Tharu and Bhote were drawn on the wall of the homestay houses. The flow of internal and international visitors was high in those communities as the women were managing everything well with the support from men. So, the buffer zone of Chitwan National Park and Amaltari Community Forest Group played a vital role as an eye-opener for the backwards society. It was then the community took the initiation of establishing homestay and used various vocational skills that helped in empowering the women.

\section{Economic Impacts of Homestay and Women Empowerment}

According to the participants of FGD, in the beginning, 10 homestay business was established but 22 more were added within four years. Now there are 32 homestays in the community. At least 32 women operating the homestay houses have received guest hospitality training. Young girls took the opportunity to learn Tharu and Bote dance and songs. Young girls and boys also learnt tourist guide skill.

Kalpana said that the Community forest group and homestay management committee provided different types of training to the women to enhancetheir skills in communication, housekeeping, kitchen management, managing health, hygiene of homestay both inside and outside. They visited different places to observe others regarding the hospitality of tourist, housekeeping, management and learned valuable knowledge and skills. Community Forest Group and Homestay Management Committee provided different skill-based training to the youths of that community. After the training, they started to produce different handicrafts at their own home targeting the visitors of that area. They enhanced their tourist guiding knowledge and skills and started to guide tourists inside the areas of Amaltari Community Forest. Kalpana excitingly added that both domestic and international tourist came to the village to enjoy the wildlife and stayed at the community homestay houses. Gradually, the flow of tourists increased which supported to increase the income of the community people as well.

Shreejana added, "Previously, the women were responsible for earning by doing labour work and the men decided on how the money would be used but now there is a mutual understanding between the men and woment about the earning, saving and appropriate use of money". She said that the economic status of the community people improved considerably. A Cooperative was established by the initiation of the community people where more than five hundred people of that community are now a member of the cooperative. Women members of the homestay houses are in the leading role. Now, they do not need to go to otheres' field to work for wage because now they have already developed themselves as an entrepreneur. There are many shops and 
restaurants in the community run by the local people. Mainly, youths are involving in the tourist guide profession. Almost all men and women are engaged in the economic and social activities of the community. Interestingly, some of them are engaged in government job whereas some are job holder in a private company or non-governmental organizations outside the community. The road has been built and access to transportation has been made easy. I observed that all the infrastructures that were developed were built in a environment-friendly manner. The community was clean and the mobility of visitors was high.

\section{Socio-Cultural Impacts of Homestay and Women Empowerment}

Because of the establishment of homestay at the Amaltari, Bagkot village the social situation of the community is drastically changed. Kalpana shared that there is a narrow gap in gender discrimination than previous. Violence against women has highly decreased. Women of homestay are now able to take the entire responsibility of community homestay management. She again added that there is now a high number of participation of women than men in the homestay management committee and they now play a vital role in decision making. Women of that community are participating in different local community-based organizations which play the role of facilitator for the development of that community.

Social status of women in that community is higher than before because of their positive role in the development of the community. Participants of focus group discussion shared that the community people take their advice before starting any new activity. Male members of the family also take consent or involve women before making any decision. The women's groups also played an important role to minimize harmful social believes and values like: early marriage, dependency on local healers and making local wine. Leadership skill in women has also been enhanced. Women easily communicate with visitors even foreigners. The community has applied a total sanitation approach. This has resulted in the improvement of sanitation of that community. People are conscious of their health, sanitation and hygiene. Health centre has been established in the community in initiation by the local people. Private clinics have also been established in the community. Besides, women of that community now go to health centres and private clinics for health service. I observed the social activities of women from these community who are are now actively taking part in the meeting of community forest group. Similarly, they were leading a community cleaning campaign. Men of that community were also together with the women in their campaign.

People of that community are conscious about their children's education including girls. A government school was established and it is well managed by the community. Women are active members of that School Management Committee and their role for preserving the school's reputation is important. Amaltari Community Forest Group is also taking responsibility of the school management. Community Forest Group and District Education Office of Nawalpur supported by providing non-formal education programs to uplift the literacy rates of women in the community. After that program, women became literate and started to read and write for their daily uses. There is formulated a paralegal committee in the community by the initiation of local government and women of that community are affiliated in the committee. If there is any case of conflict, that paralegal committee takes initiation for managing the conflict.

\section{Political Impacts of Homestay and Women Empowerment}

Homestay came as an opportunity for the women of the village because their capacities in different aspects were enhanced. After participating in different training and exposer visits, it was easier for them to take a leadership role at the local level. Shreejana shared that she was elected in the School Management Committee. She now has an important decisionmaking role in the committee. Women of that community were elected in Community Forest Group, 
Cooperative, Water Supply and Sanitation User Committee and Tole Development Organizations. Not only this but a woman from that community particularly homestay village also got elected in the Municipality Executive Board. Participants of focus group discussion shared that the women of that community can now express the issues of all women, children, ageing people and their community in the Municipality Board. Women of this community can take the initiation if any issue occurrs in the community through discussion and find a solution. They can now use their voting rights without any fear and hesitation.

Bote and Tharu community each have their own rich culture but they were not much conscious about it before establishing the homestay. Culturally, many activities and behaviours are more related with the women than men such as wearing traditional clothes, worshipping, singing, dancing, making dresses, use of jewellery, food, making handicrafts, house management and many more. However, there was a threat of losing these cultural identities because the Tharu and Bote people were not concerned. After establishing the homestay in that village, women and men became ore conscious about their culture because visitors came there to observe the Tharu and Bote culture. Their culture is now the major cause of attraction for both the internal and international tourist. Meena shared that, "My daughter did not like Tharu culture. When Community Forest Group and Homestay Management Committee provided training, she started to sing traditional Tharu songs well and dance in different Tharu songs". Young women and men learnt traditional Tharu and Bote songs and dances. Now they are entertain more with their indigenous fashion, food, dance, song, rituals and festivals than with others' culture.

Many visitors come to the homestay and entertain with the local culture. Cultural Museum of Bote and Tharu has been established in the community with the initiation of Amaltari Community Forest Group and Homestay Management Committee. There were few bad traditions in the culture of Tharu and Bote such as maximum use of local wine during festivals and rituals. This tradition was the main cause of violence against women. With the initiation from the women of the community, such types of bad traditions have drastically reduced.

\section{Conclusion}

Amaltari community homestay has played a vital role in continuing the traditional skills, which were identities of the Tharu and Bote Community. Along with the changing time, many modern vocational skills are also introduced in the community with the establishment of Community homestay. The skills have been an important tool to empower them economically, socially, politically and culturally. Thus, the vocational skill can be a tool to enhance the people's lives, particularly of a marginalized community.

\section{References}

Al-Momani, M. (2019). Empowering women's role through technical and vocational programs: A Northern Jordan case study. Educational Research, 10(1), 214-222. https://www.doi. org/10.14303/er.2019.235

Asian Development Bank. (2015). Innovative strategies in technical and vocational education and training for acceleterated human resource development in South Asia: Nepal. Retrived from https://www.adb.org/sites/default/files/ publication/176564/tvet-hrd-south-asia-nepal.pdf

Bagale, S. (2015), Technical education and vocational training for sustainable development. Journal of Training and Development, 1(1), 15-20.

Bhattachan K. B. (2012). Country Technical Notes on Indigenous Peoples' Issues, Federal Democratic Republic of Nepal. International Fund for Agricultural Development.

Eigbiremolen, G.O., \& Anaduaka, U. S. (2014), Human capital development and economic growth: The Nigeria experience. International Journal of Academic Research in Business and Social Sciences, 4(4), 25-35. 
Government of Nepal. (2012). National population and housing census 2011 (National report). National Planning Commission Secretariat \& Central Bureau of Statistics.

Jha, H. B. (2019). The janajati of Nepal. Vivekananda International Foundation.

Korstjens, I., \& Moser, A. (2018). Series: Practical guidance to qualitative research. Part 4: Trustworthiness and publishing. European Journal of General Practice, 24(1), 120-124. https://www.doi.org/10.1080/13814788.2017. 1375092

Limbu R., K. (2015). Rhetoric of state ideology and ethnic identity in Nepal. Journal of Indigenous Nationalities, 14(6). 125-145.

Luithue, S., \& Tugendhar H. (2013). Violence against women and girls: a complex phenomena. Asia Indigenous People Pact Foundation Thailand and Forest Peoples Programme UK.

Luttrell, C., Quiroz, S., Scrutton, C., \& Bird, K. (2009). Understanding and operationalising empowerment, working paper 308. Overseas Development Institute.

Matovac, V. A., Bilas, V., \& Franc, S. (2010). Understanding the importance of human capital and labor market competitiveness in the EU candidate countries and selected EU members. Ekon. Misao Praksa Dbk. God, 19(2), 359-382.

Morrow L. S. (2005). Quality and trustworthiness in qualitative research in counseling psychology. Journal of Counseling Psychology. 52(2), 250-260.

Nagy, R. (2015). Combatting violence against indigenous women. In A. Powell, N. Henry, \& A. Flynn (Eds), Rape Justice. Palgrave Machmillan. https://www. doi.org/10. 1057/9781137476

National Indigenous Women Federation. (2018).
Economic empowerment of indigenous women in Nepal. Author.

National Planning Commission. (2017). National review of sustainable development goals. Author.

Nepal Law Commission. (2015). Constitution of Nepal. Author.

National Planning Commission. (2015). Sustainable development goals 2016-2030, national (preliminary) report. Author.

National Planning Commission. (2017). Nepal's sustainable development goals: baseline report. Author.

Perkins D. D., \& Zimmerman, M. (1995). Empowerment theory, research, and application. American Journal of Community Psychology. 23(5), 569-579.

Roy, C., Chatterjee, S., \& Gupta, S. D. (2018). Women empowerment index: Construction of a tool to measure rural women empowerment level in India. International Journal of Management, Anveshak: International Journal of Management, 7(1), 199-212.

Sharma, P. R. (2007). Micro-finance and women empowerment. Journal of Nepalese Business Studies. 4(1), 16-27. https://www.doi.org/10. 3126/jnbs.v4i1.1026

Tengland, P. A. (2007). Empowerment: A conceptual discussion. Health Care Analysis, 16(2), 77-96. https//www.org/10.1007/s10728-007-0067-3

United Nations. (2015). Transforming our world: The 2030 agenda for sustainable development. https://sustainabledevelopment.un.org/post 2015/transformingourworld

Zimmerman M. A. (2000). Empowerment theory. In J. Rappaport, E. Seidman (Eds), Handbook of Community Psychology (p. 43-63). Springer. 